\title{
Access to Finance as a Driver Innovation
}

\author{
Iryna Vasylchuk $^{1^{*}}$, Natalya Izmaylova ${ }^{1}$, Olga Smyrna $^{1}$, Tetiana Petrishyna ${ }^{1}$ and Kateryna Slusarenko ${ }^{1}$ \\ ${ }^{1}$ State University of Economics and Technology, Kryvyi Rih, 50000, Ukraine
}

\begin{abstract}
Innovation accelerates economic growth and becomes the key to success in the new postindustrial paradigm. The more innovation, the more a country's prosperity grows. Innovation is a risky and costly type of activity, so it requires significant financial resources attracted from different sources and by different methods. Traditionally, the entrepreneurial sector, which has sufficient amounts of various resources, is the most innovatively active. At the same time, the innovative activity of companies is under pressure from a number of factors. The purpose of the article is to analyze the factors influencing the innovative activity of industrial enterprises in Ukraine and to identify the relationship between the volume of innovation and economic growth of the country. For the analysis there were used the methods of descriptive, comparative and correlation and regression analysis. The sample is created at the basis of data from statistical reports on the research and development activities of economic entities in Ukraine for the period 2000-2019.It has been revealed that there is a steady decline in the number of workers in the innovation sphere in Ukraine, and compared to European countries, these indicators are much lower and tend to decrease further. This affects the place of Ukraine in the global ranking of innovation in a negative way. It is confirmed that there is a direct positive significant relationship between the costs of innovation and bank loans and foreign direct investment in the capital of Ukrainian companies, confirms the thesis of funding as a driver of innovation. It is confirmed for Ukrainian content that there is a positive relationship between innovation and economic growth.
\end{abstract}

\section{Introduction}

R\&D and innovation is an important factor in a country's economic growth and prosperity, and contributes to its competitiveness in the modern world. Even small and resource-poor countries achieve a high level of economic development with the introduction of disruptive technologies and organizational and product innovations. In order to become successful in the new post-industrial paradigm, the state and business must significantly increase the volume of spending on innovation and science, create conditions for replication and multiplication of innovation, develop the entrepreneurship sector, inculcate the ideology of creativity, innovation and enterprise in society. An important condition for achieving a technological breakthrough is access to funding. And while public sector research institutions can rely on funding from the state budget, business can rely primarily on internal resources and funds raised from the financial market. In conditions of underdevelopment of stock market in Ukraine, and as a consequence, its inability to absorb financial capital and fulfill its mission of provider of capital, low volumes of business crediting by credit institutions, chronic shortage of own funds of enterprises as a result of permanent economic recession, business suffers from inability to activate and finance innovation activity.

The aim of the article is to analyze the factors influencing the innovative activity of industrial enterprises in Ukraine and to identify the relationship between innovation and economic growth of the country. From the above, the task of this study is to find answers to the following research questions:

RQ1. Do macroeconomic factors influence the innovative development of the country and the innovative activity of Ukrainian companies?

$R Q 2$. Is the determinant of human capital significant for the level of innovativeness of the country's economy?

$R Q 3$. Does company size influence the level of its innovative efficiency and the amount of expenditure on innovation?

$R Q 4$. Does the company's access to financing from various sources and forms of attraction affect the amount of innovation expenditures?

$R Q 5$. Is there a positive relationship between the $R \& D$ expenditure on innovation of industrial companies and the economic growth of the country?

To find answers to these questions, there were used descriptive, comparative and correlation-regression analysis methods. The sample is created at the basis of data from statistical reports on the research and development activities of economic entities in Ukraine and on the Statistical Yearbook of Ukraine for the period 2000-2019.

\subsection{Literature review}

At the beginning of the study it is necessary to define the main terms. In scientific publications, the innovative activity of companies is understood as an activity, action

${ }^{*}$ Corresponding author: vasylchuk ip@duet.edu.ua 
or set of activities aimed at creating a new product or its significant improvement, in order to obtain commercial benefits and competitive advantages of innovation-active enterprise [1-5]. It is important to emphasize that it is an activity aimed at the use and commercialization of R\&D results and predetermines the release of new competitive goods and services to the market [report]. So, innovative activity leads to development. In turn, the innovative development of the enterprise is defined as positive qualitative changes in the state of the enterprise as a result of the implementation of innovative activity and effective use of innovative potential [2]. It can be assessed by the level of implementation of innovation, namely by the achieved level of practical use of inventions, research results, technologies and other innovations [3]. There are innovatively active and innovatively capable enterprises. Innovation-active enterprise is an enterprise that was engaged in innovative activities (developed or implemented new or improved products and innovative processes) during a certain period of observation [6].

The innovative ability of the enterprise should be understood as the ability to carry out innovations at the expense of the models of the corresponding resources financial, human, physical, organizational, and so on. The absence of a certain type of resource in sufficient volumes reduces or eliminates the company's ability to carry out innovative activities.

At the same time, implementation of scientific research, introduction of innovations requires appropriate expenses. The innovation expenditure is understood as the cost of the enterprise to implement innovations both new to the enterprise, and new to the market, including: internal $R \& D$, acquisition of $R \& D$ results, machinery, equipment and software, other external knowledge and other costs [6]. The innovative activity of the enterprise depends on the influence of various factors. Ukrainian scientists noted that among the factors hindering the activation of innovative activity of domestic enterprises the main ones are such as imperfect legislative base, lack of financial resources and weak incentives for implementation of inventions, research and technology [6]. In the study [3] based on the results of the survey, the author identifies such factors as the lack of own funds of the enterprise (15.6\%); high costs of innovation (13.3\%); lack of funding from external sources $(8.4 \%)$; dominant market role of individual enterprises $(7.7 \%)$; difficulties in finding partners for innovation $(5.5 \%)$; low demand for innovative products or services $(4.6 \%)$. In another study [7] we find that the main barriers to innovation activity of Ukrainian enterprises are as follows: lack of own funds $(83.0 \%$ of surveyed enterprises), high costs of innovation $(55.9 \%)$, insufficient financial support from the state $(56.6 \%)$, high economic risk $(38.9 \%)$, long payback period of innovation (34.6\%). In addition, the development of innovation activity was restrained by the imperfect legal framework $(37.7 \%)$, lack of demand for the products $(16 \%)$ and qualified personnel $(17.2 \%)$. As wee can see, the overwhelming majority of scientists identify the factor of lack of financial resources from various sources as one of the most significant factors of influence on the innovation activities of enterprises.

In their studies domestic scientists use mainly descriptive and comparative methods of analysis, while the vast majority of scientists base their research on the use of other analytical methods, in particular methods of econometric analysis. A significant number of publications [8-11] are devoted to assessing the relationship between innovation and economic growth. Scientists have found that innovation activity is equally influenced by economic growth and other macroeconomic factors. This means that in practice both innovation activity and economic growth can condition each other and, therefore, there is a possibility of feedback between them. Also for different jurisdictions the factors of influence on innovation are investigated [11], [12-13]. Thus, K. Širec and D.Močnik [14] evaluated the relationship between firms' innovation activities and the education of their owner-managers, firms' international orientation and their growth aspirations. M. Bhattacharya and H. Bloch [13] investigated how firm size, market structure, profitability and growth affect the innovation activities of small and medium-sized businesses. A. Pecea et al. [9] used such factors as the number of patents, number of trademarks, R\&D expenditures as determinants of economic growth and innovation. In [15-16], considerable attention is paid to the influence of such factors as external direct investment, access to credit resources, the state of development of the stock market and the like on the innovative activity of companies. The authors [15] discovered that the companies with participation of the foreign capital or having good access to domestic bank loans are more innovatively active, than others.

However, existing studies have not carried out a quantitative assessment of the impact of determinants on the innovative activity of Ukrainian companies and did not study the relationship between innovation and economic growth and well-being of the country.

\section{Hypotheses Development and descriptive data analysis}

\subsection{Innovation and macroeconomic indicators of economic development}

Innovation activity, as well as investment activity, in countries depends on the trends of global and national economies and fits into certain cycles. According to the research [17] at the global level, historically it has been noticed that business R\&D expenditure, investments in intellectual property and venture capital moved in line with GDP, slowing down noticeably during the economic downturn of the early 1990s, early 2000s and 2009 [18]. Ukraine isn't an exception and trends of innovation activity development in the country as a whole and business R\&D activity also move cyclically (Fig.1). Thus, between 2000-2006 the economy of Ukraine was on the rise, GDP was gradually growing, and against this background the indicators of innovative activity of Ukrainian companies were gradually 
increasing. In addition, after the victory of the "orange" revolution in Ukraine (2004), international investors became more interested in Ukrainian companies, which contributed to a surge in their business activity, improvement of the investment climate and inflow of funds. In the period before the global financial crisis (2006-2008) the volume of foreign direct investment in Ukraine increased significantly, the interest rates on loans decreased significantly, which led to an increase in lending to the economy and the total amount of available financial resources (Fig. 2).

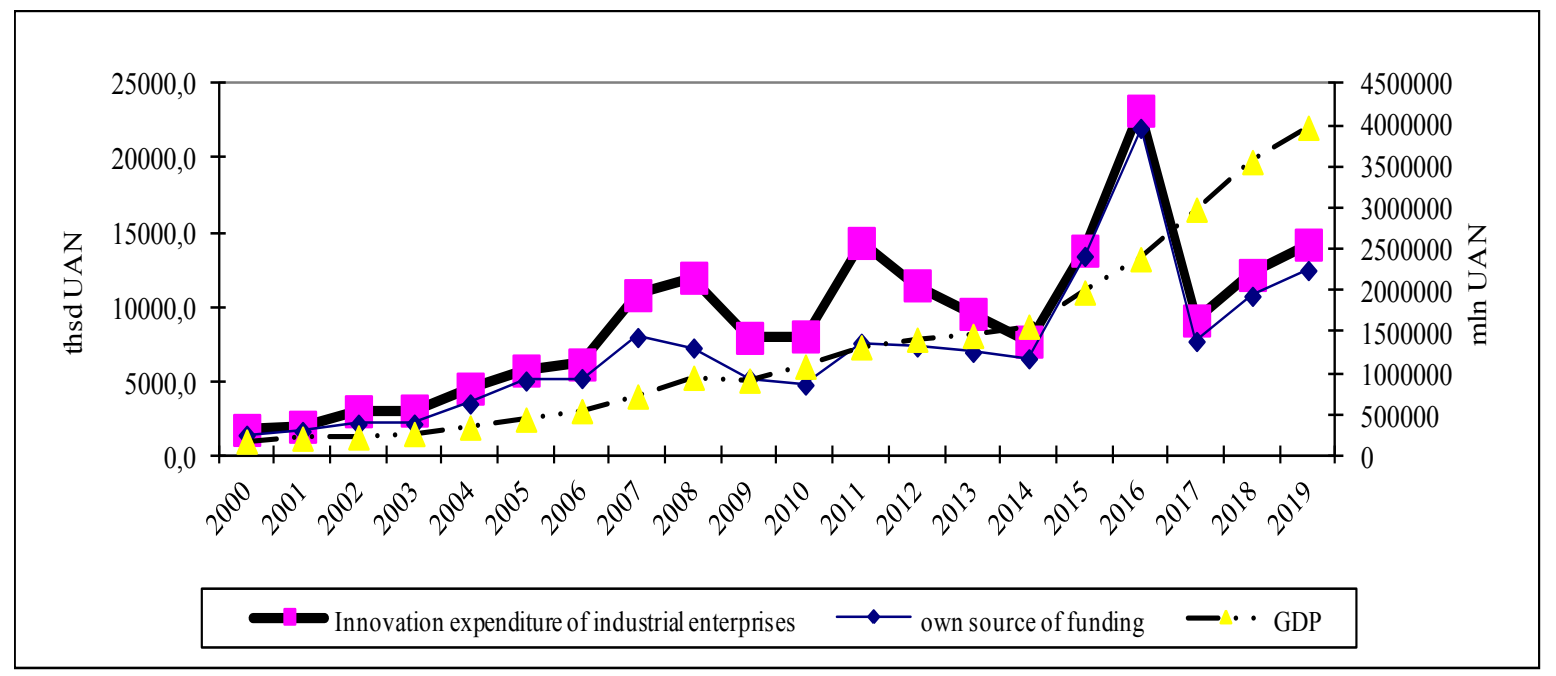

Fig. 1. Ukrainian GDP, business R\&D expenditure and innovation expenditure of industrial enterprises by source of own funding in 2000-2019

Source: constructed by the author according to [6], [19-21], [23]

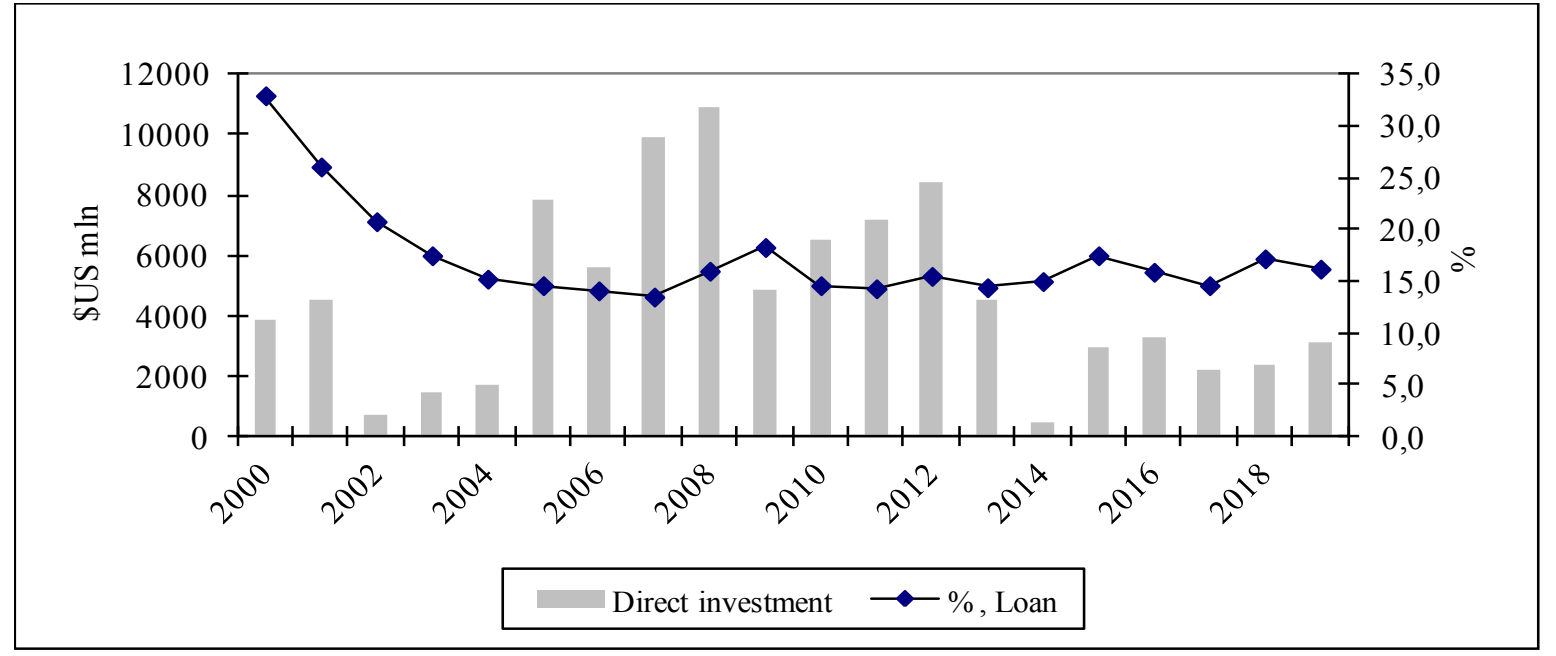

Fig. 2. Foreign direct investment and \% on loans in Ukraine in 2000-2019

* 2000-2004 with interest accrued; including loans to the government sector; 2005-2019 loans to nonfinancial corporations Source: constructed by the author according to [6], [19-23]

In the period after the financial crisis (2009-2010) the volume of business $\mathrm{R} \& \mathrm{D}$ expenditure dropped significantly, and already in 2011 there was a significant "rebound", although in next years (2012-2014) research expenditure decreased again, which was due to domestic political and economic factors (annexation of Crimea, military actions in the East of Ukraine). In 2016, Ukraine's economy finally stabilized, the demand for the main export products of domestic producers intensified, which caused a "surge" of spending on innovation activities. However, in next years, the volume of innovation expenditures already had a moderate upward trend. Thus, the analysis allows us to confirm the research question $R Q 1$ and claim that innovative expenses of companies are influenced by trends in the economy, including the main macroeconomic indicators. We can see (Fig. 2) an inverse relationship between the volume of foreign direct investment and interest rates on loans, which confirms the stimulating role of the interest rate and the weighted monetary policy.

To assess the general state of innovativeness of the country's economy the share of total intramural R\&D expenditure in GDP is calculated, the level of which in Ukraine is too low compared to European countries and 
has a decreasing tendency (Fig. 3). Thus, if in 2010 the share of $\mathrm{R} \& \mathrm{D}$ expenditure was $0,75 \%$, for the last 10 years it has decreased to $0,43 \%$, whereas for the totality of European countries during the same period the indicator has increased from $1,92 \%$ to $2,12 \%$.

The level of innovativeness of the country's economy can be evidenced by its rating in global indices. In particular, in 2019, according to the "Global Innovation Index - 2020" calculated by the international business school INSEAD, the World Intellectual Property Organization and Cornell University, Ukraine took 45th place out of 130 in the ranking of the most innovative countries in the world, remaining at a relatively low position, and maintained 2nd place among "countries with income below average" in the sub-index [24].

If we analyze the total expenditure in $\mathrm{R} \& \mathrm{D}$ in Ukraine according to their distribution by sectors of activity (Fig. 4), we can see that traditionally the main driver of innovation in Ukraine is business, the share of which is more than $58 \%$ of the total costs. So, we can consider that the success of innovative activity of the business sector, in particular industry, to a great extent determines the success of innovative development of the country as a whole. Therefore, the results of innovative activity of industrial enterprises in Ukraine require more detailed research.

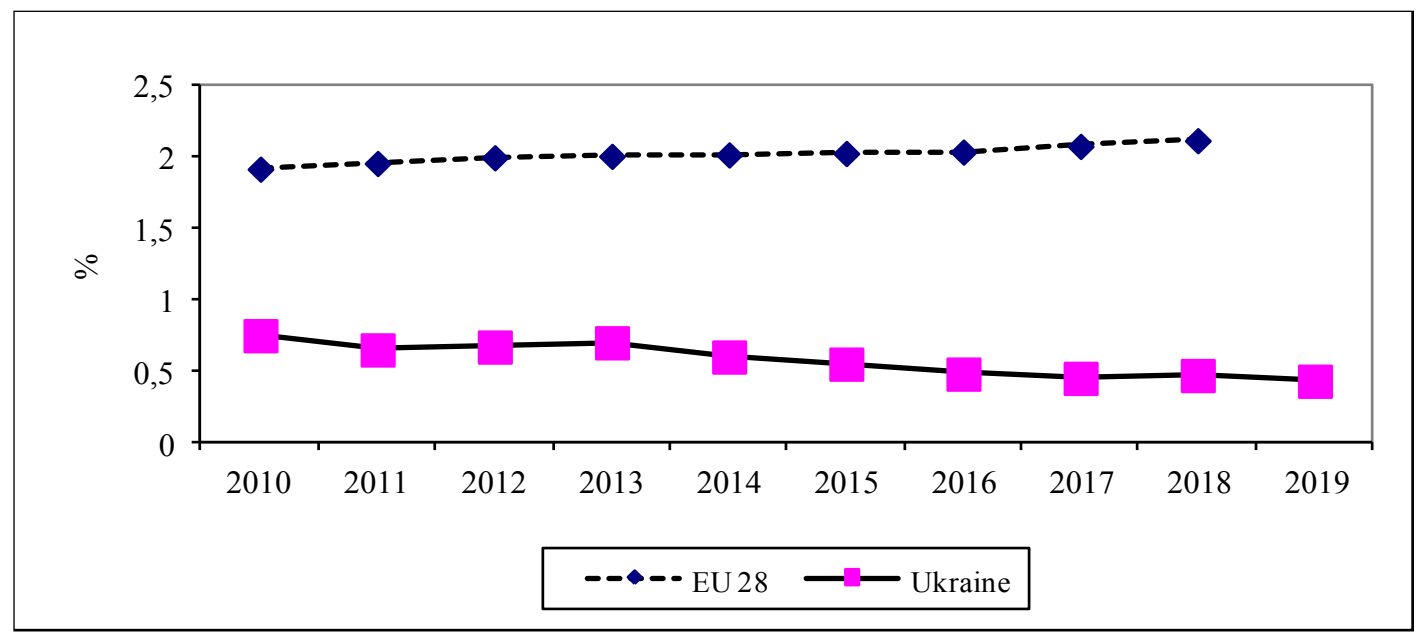

Fig. 3. Share of intramural R\&D expenditure in GDP in 2010-2019

Source: constructed by the author according to [19]

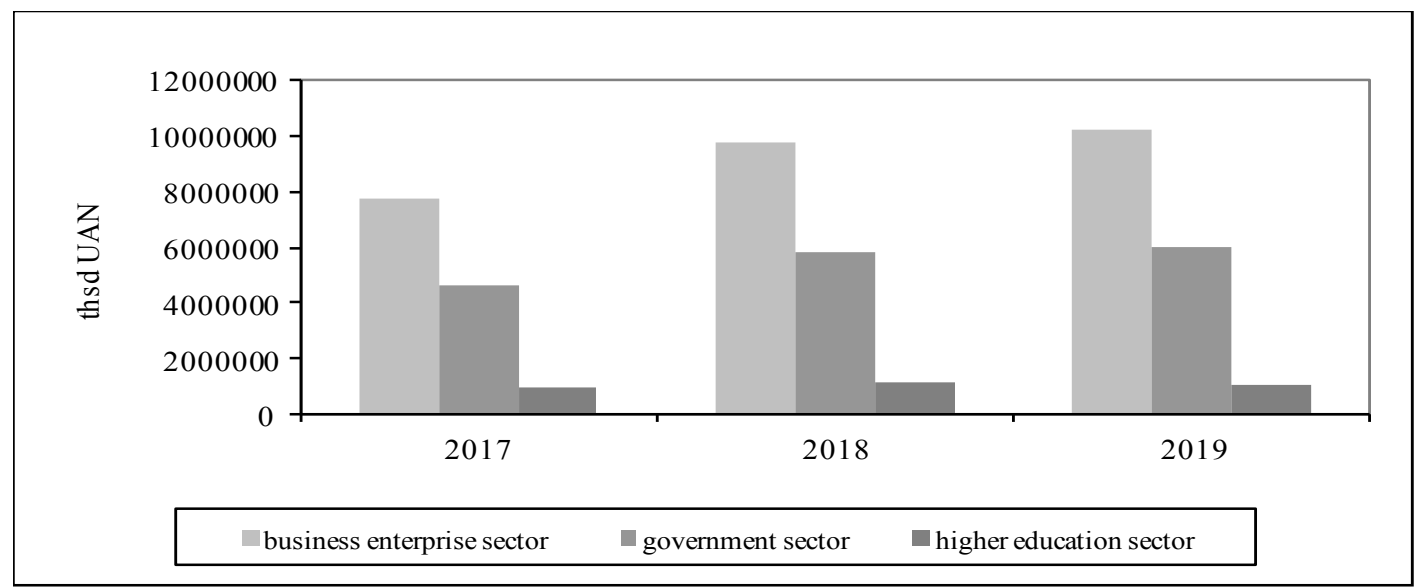

Fig. 4. Intramural R\&D expenditure by sectors of performance in Ukraine in 2017-2019

Source: constructed by the author according to [19]

\subsection{Innovations and human capital}

One of the important factors influencing the innovative activity of business and the country as a whole researchers determine a sufficient number of employees with a high level of education. It has been confirmed [9, 14] that the innovation activity and potential of enterprises is directly influenced by the education of managers and researchers, in particular above. Higher education provides the opportunity to possess more modern knowledge and research competencies, to be erudite on a wide range of issues, to be able to constantly learn and seek necessary information. In addition, the more high-level workers are engaged in R\&D research, the more new products and technologies they can implement and produce more innovative products. In Ukraine there has been steady decline in the number of employees and researchers engaged in $R \& D$ over the past 10 years (Fig.5).

Thus, the number of highly qualified researchers decreased by more than 2.6 times from 133.7 thousand people in 2010 to 51.1 thousand people in 2019, and their share in the total employed population at the end of 2019 is only $0.31 \%$. 


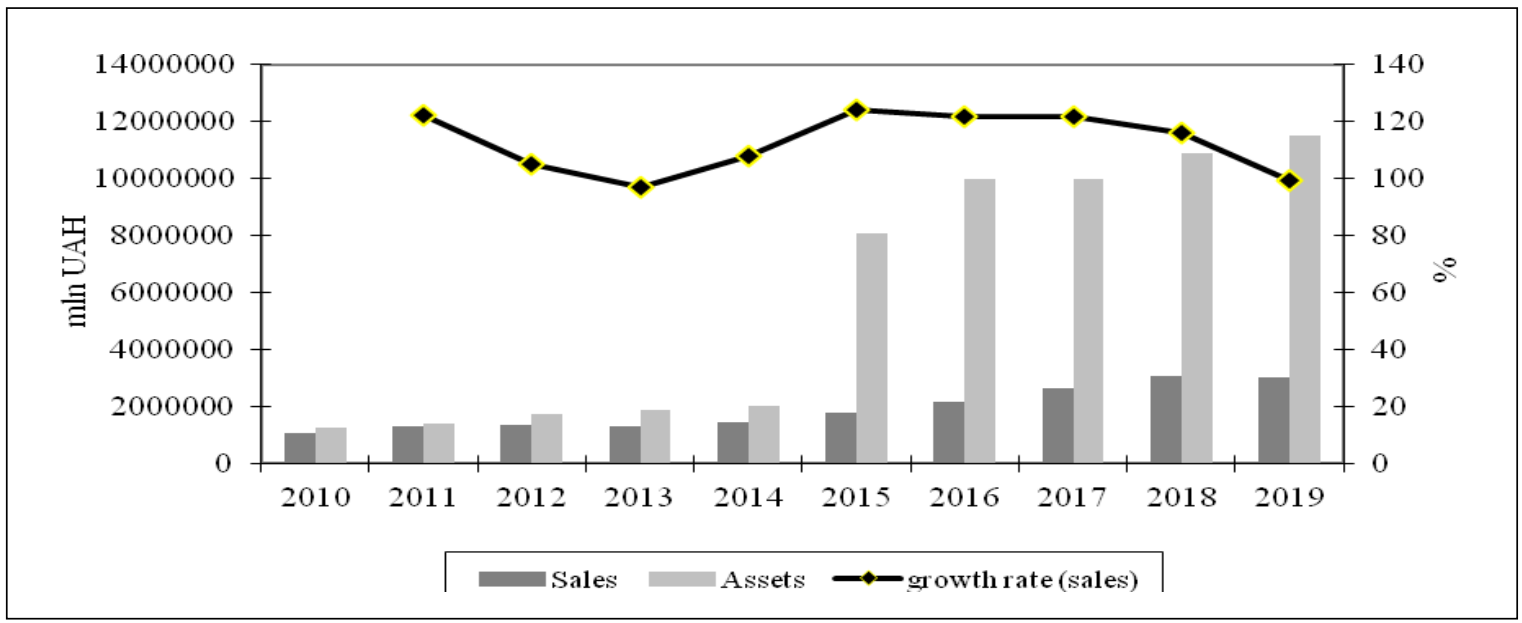

Fig. 5. Dynamics of the number of employees and researchers engaged in R\&D in Ukraine in 2010-2019 Source: constructed by the author according to [6], [19-21]

So, we can see a significant reduction in human capacity for research and innovation, which does not strengthen the position of Ukraine in the ranking of innovative countries and worsens its ability to innovate.

A comparative analysis of the number of workers and researchers involved in research in Ukraine and Europe per 1000 people employed found a low level of this indicator. For example, in 2010 in EU 28 the rate of workers was almost 18 workers per 1,000 population and researchers more than 11.5 , in 2019 the rate rose to 21.6 and 14.0 for workers and researchers, respectively.
While Europe is increasing its human capacity for innovation, in Ukraine the indicator for workers is almost half as low in 2010 (9.5 people), and in 2019 the gap increases to 4 times and is 5.8 workers per 1000 people of population [6]. We observe the same trends for researchers, that is, there is a deterioration of scientific and human capital potential due to many reasons, including the outflow of "brains" to other countries.

The connection between the number of innovation workers and the share of R\&D expenditure in GDP can be shown by the results of comparative indicators calculations (Table 1).

Table 1. Comparative indicators Share of intramural R\&D expenditure in GDP and Number of R\&D personnel per 1000 persons (EU-28 vs Ukraine)

\begin{tabular}{|c|l|c|c|c|c|}
\hline \multirow{2}{*}{ Ino } & \multicolumn{1}{|c|}{ Years } \\
\cline { 3 - 6 } & & $\mathbf{2 0 1 0}$ & $\mathbf{2 0 1 5}$ & $\mathbf{2 0 1 7}$ & $\mathbf{2 0 1 7 / 2 0 1 0}$ \\
\hline 1 & Share of intramural R\&D expenditure in GDP (EU-28), \% & 1,92 & 2,03 & 2,08 & 1,08 \\
\hline 2 & Share of intramural R\&D expenditure in GDP (Ukraine) & 0,75 & 0,55 & 0,45 & $\mathbf{0 , 6 0}$ \\
\hline 3 & Excess (multiplicity)(line 1 / line 2) & 2,6 & 3,7 & 4,6 & 1,78 \\
\hline 4 & Number of R\&D personnel per 1000 persons (EU-28) & 17,9 & 20,4 & 21,6 & 1,21 \\
\hline 5 & Number of R\&D personnel per 1000 persons (Ukraine) & 9,5 & 9,1 & 5,8 & $\mathbf{0 , 6 1}$ \\
\hline 6 & Excess (multiplicity) (line 4 / line 5) & 1,9 & 2,2 & 3,7 & 1,95 \\
\hline
\end{tabular}

Source: calculated by the author according to [6]

The calculations show that in 2010 R\&D expenditure in GDP in EU-28 exceeded the same indicator for Ukraine by 2.6 times, and already in 2017 the excess was 4.6 times. The growth rate of the indicator for Ukraine was $60 \%$ compared to 2017 before 2010 . The excess of the number of innovative workers per 1000 people in the EU over the same indicator for Ukraine in 2010 was 1.9 times, and already in $2017-3.7$ times. The growth rate of this indicator for Ukraine was $61 \%$ compared to 2017 before 2010 .

Thus, we can see that the fall in the number of employees in the sphere of $\mathrm{R} \& \mathrm{D}$ directly leads to a decrease in the share of spending on innovation in GDP which provides an answer to the research question $R Q 2$ and confirms the importance of the determinant of human capital for the level of innovativeness of the economy.

\subsection{Innovation, Firm Size and Growth}

Studies [9, 11-13] show that there is a direct link between firm size, firm growth and innovation activity. It is proved that large companies have much more opportunities and resources (financial, human, technical, technological, etc.) to conduct research in the development of new technologies, products, organizational innovations, than small companies. Large companies have sufficient amounts of liquid funds and long-term capital, more often have balanced portfolios of clients and suppliers, and a higher "appetite for risk".

Therefore, large companies often win in the competition, although sometimes small firms can be more innovative, for example in the field of IT technology. At the same time, large international companies have the opportunity to use and implement the developments of «parent» companies, which also provides a competitive advantage. Analysis of large companies shows that for many of them investment in $\mathrm{R} \& \mathrm{D}$ remains a priority even in times of unfavorable economic conditions. This allows them to achieve strategic benefits, enter new markets and strengthen their positions in the industry after the crisis [25]. Researchers 
have proved a positive relationship between the growth of the firm and an increase in its innovative activity for companies from different jurisdictions. Extrapolation to the macro level confirms the following dependence: the more developed economy, the more innovations in it and vice versa [17]. So, it is possible to consider the size of the company as a factor of influence on innovative activity and innovative ability of the company.

The size of the company can be assessed by indicators of the size of its assets or the volume of revenues.

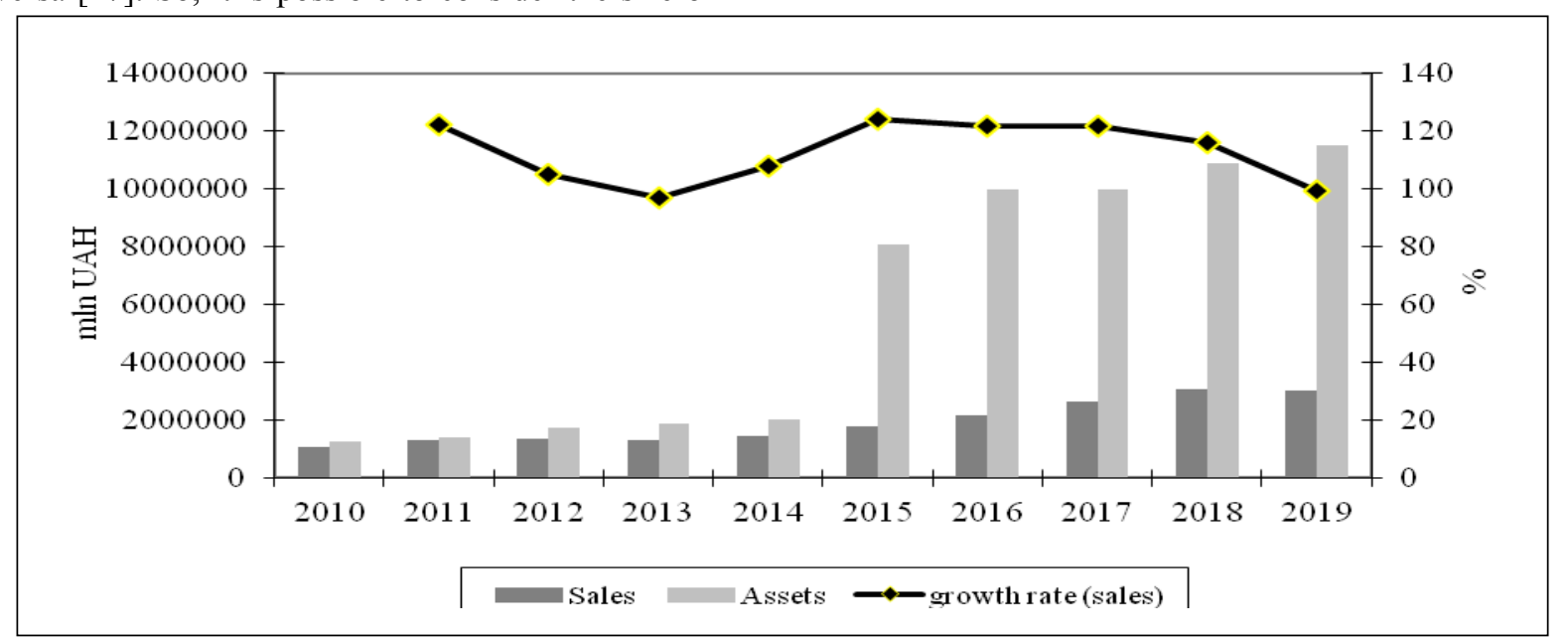

Fig. 6. Dynamics of company size indicators in Ukraine for 2010-2019 Source: constructed by the author according to [19-20]

Analysis years (Fig. 6) shows a gradual increase in revenues, beginning in 2013, although in 2019 we can see a drop in revenues. At the same time, the size of companies' assets grew very significantly after 2015, almost 4-fold compared to 2014, and almost 6-fold in 2019. Since quite often the size of assets of industrial enterprises grows at the expense of increasing the volume of accounts receivable, which is essentially deferred income, so to estimate the size of Ukrainian enterprises should choose the indicator of the volume of proceeds from the sale of products. Based on the above and to obtain an answer to the research question $R Q 3$ we put forward a hypothesis:

H1: there is a positive relationship between companies' size and total innovation expenditure of industrial enterprises (determinant-companies' size (sales)).

\section{4 Innovation and access to financing}

The availability of funding for research and development, implementation of innovations and development of innovative products is undoubtedly an important factor in enhancing the innovative activity of companies. In researches [15-16], [26-29] the direct positive connection between development of the financial market, foreign direct investment, access to finance, and innovation activity on the example of Chinese companies is proved. Scientists note that the cost of innovation requires significant amounts of financial resources received from various sources. For long-term and high-cost developments associated with significant risks, it is quite difficult to be limited to domestic sources of financing. Therefore, the more developed is the financial market, the more opportunities for companies to finance scientific development, the more innovative products can be obtained on the output.
The study [17] explicitly states that the lack of funding sources due to imperfect capital market and other reasons can lead to an insufficient level of investment in innovation. In addition, the technological risk associated with innovation may be too high for entrepreneurs and investors, so it is important to have a portfolio of financial resources diversified by sources, methods and instruments.

Analysis of the sources of funding for innovation in Ukraine has shown that the main source of funding for innovation of industrial enterprises is domestic resources, the share of which ranges from $52.9 \%$ in 2011 to a record $97.2 \%$ in 2015 and $87.7 \%$ in 2019 (Fig. 7)

A detailed analysis of the structure of sources of funding for innovation expenditures of industrial enterprises (table 2) revealed that the share of budget financing (from all levels) is too low, but tends to increase - from $1.2 \%$ in 2010 to $3.7 \%$ in 2019 . The share of bank lending is also insignificant, only $6 \%$ in 2019 , although in 2011 the share of loans in financing enterprise innovation was more than $38 \%$.

We can see that the banking sector in Ukraine in recent years does not fulfill its role in lending to the economy, but acts as an active player in the market of government bonds.

Foreign investors are reluctant to invest into domestic enterprises, same way other forms and methods of financing innovative activity of companies are not being used. In fact, neither credit nor stock market is functioning in Ukraine, which makes entrepreneurs count only on their own resources. In such a situation the ability to implement "disruptive" technologies and develop innovative products in domestic enterprises is limited, which "conserves" the country's economy in the old industrial paradigm and dooms it to lagging behind. 


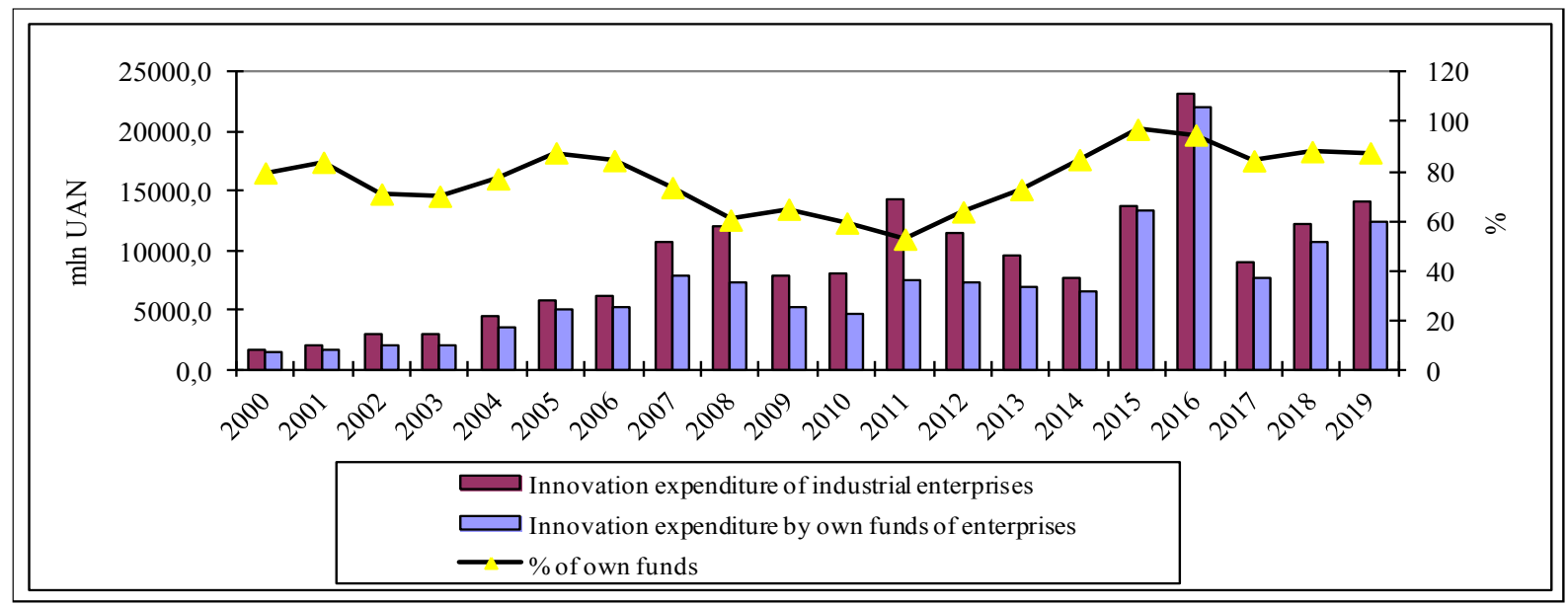

Fig. 7. Dynamics and share of financing of investment expenditures at the expense of own funds of enterprises in Ukraine in 20102019

Source: constructed by the author according to [6], [19-21]

Table 2. Structure of financing sources for innovation of industrial enterprises in Ukraine in 2010-2019

\begin{tabular}{|l|c|c|c|c|c|c|c|c|c|c|c|}
\hline \multirow{2}{*}{$\begin{array}{l}\text { Source of } \\
\text { funding }\end{array}$} & \multicolumn{9}{|c|}{ Years } \\
\cline { 2 - 12 } & $\mathbf{2 0 1 0}$ & $\mathbf{2 0 1 1}$ & $\mathbf{2 0 1 2}$ & $\mathbf{2 0 1 3}$ & $\mathbf{2 0 1 4}$ & $\mathbf{2 0 1 5}$ & $\mathbf{2 0 1 6}$ & $\mathbf{2 0 1 7}$ & $\mathbf{2 0 1 8}$ & $\mathbf{2 0 1 9}$ \\
\hline $\begin{array}{l}\text { Total innovation } \\
\text { expenditure, }\end{array}$ & 100 & 100 & 100 & 100 & 100 & 100 & 100 & 100 & 100 & 100 \\
\hline \multicolumn{8}{|c|}{ of them due to } \\
\hline $\begin{array}{l}\text { - own funds of } \\
\text { enterprises }\end{array}$ & 59,3 & 52,9 & 63,8 & 72,9 & 85,0 & 97,2 & 94,9 & 84,5 & 88,2 & 87,7 \\
\hline $\begin{array}{l}\text { - state budget } \\
\text { funds }\end{array}$ & 1,1 & 1,0 & 2,0 & 0,3 & 4,5 & 0,4 & 0,8 & 2,5 & 5,2 & 3,9 \\
\hline $\begin{array}{l}\text { - funds from local } \\
\text { budgets }\end{array}$ & 0,1 & 0,1 & 0,1 & 1,6 & 0,1 & 0,3 & 0,4 & 1,0 & 0,1 & 0,8 \\
\hline $\begin{array}{l}\text { - funds of } \\
\text { resident investors }\end{array}$ & 0,4 & 0,3 & 1,3 & 1,3 & 0,1 & 0,6 & 0,6 & 3,0 & 0,9 & 0,5 \\
\hline $\begin{array}{l}- \text { funds of non- } \\
\text { resident investors }\end{array}$ & 30,0 & 0,4 & 8,7 & 13,1 & 1,8 & 0,4 & 0,1 & 1,2 & 0,9 & 0,3 \\
\hline - loans & 7,8 & 38,3 & 21,0 & 6,6 & 7,3 & 0,8 & 2,7 & 6,5 & 3,9 & 6,0 \\
\hline $\begin{array}{l}\text { - funds of other } \\
\text { sources }\end{array}$ & 1,3 & 7,0 & 3,0 & 4,2 & 1,2 & 0,3 & 0,5 & 1,3 & 0,8 & 0,8 \\
\hline
\end{tabular}

Source: grouped by the author according to [6]

The importance of sufficient funding for innovation and research and easy access to various forms and sources of financing innovation for business is recognized at the global level. The "Global Innovation Index 2020" [17] asks as a headline question: Who Will Finance Innovation? As countries and innovative companies use a wide range a result, the study notes that in today's environment, of mechanisms to finance innovation, in particular corporate venturing, intellectual property (IP) marketplaces, microfinance, crowdfunding, and Fintech solutions [17].

In the conditions of Ukraine it is possible to rely so far on the traditional mechanisms - the funds of shareholders (investments of residents and non-residents in the share capital) and creditors, which form a pool of available resources for the company. On this basis, we formulate hypotheses to obtain an answer to the research question RQ4:

H2: there is a positive relationship between amount of loans granted to non-financial corporations and total innovation expenditure of industrial enterprises (determinant-loans).

H3: there is a positive relationship between volumes of foreign direct investment and total innovation expenditure of industrial enterprises (determinant foreign direct investment).

\subsection{Economic Growth and Innovation}

It is almost axiomatic that innovation has a positive effect on economic growth and welfare both at the level of individual economies and individual business entities. Since J. Schumpeter, numerous scientific publications [8-11], [17], [30-32] have expressed the opinion and received empirical evidence that innovation acts as a driver of economic development for both developed and emerging economies. Innovation, R\&D expenditure and investment in technology are prerequisites for competitiveness and progress, and through them sustainable economic growth [9]. Thus, innovation activity has a great influence on the development of the country's economy and is the basis for economic, technological, political, ecological and social development of society [31].

At the same time, it has been confirmed that it is 
economic growth that can increase the level of innovativeness of the economy, so scholars [8], [10] postulate a two-way causal relationship between innovation and economic growth. Accepting the view that there is a two-way causal relationship between economic growth and innovation and it is relevant to countries with different levels of economic development we put forward the following hypothesis:

H4: there is a positive relationship between total innovation expenditure of industrial enterprises and Gross Domestic Products (determinant - total innovation expenditure of industrial enterprises).

\section{Research Method}

According to the hypotheses raised and to the results of descriptive and comparative analyzes for Ukraine, the study has analyzed the relevant factors of innovation for the Ukrainian industrial companies. The independent changes that were selected for the regression analysis have already been tested for other jurisdictions and are based on the results of previously published prior empirical studies [9-11], [13], [15-16], [26-30]. This study has employed six variables: total innovation expenditures of industrial enterprises (TIE), sales of industrial enterprises (approximates the size of the company), bank loans to non-financial corporations (BL), foreign direct investment (FDI), share of innovatively active enterprises in the total number of industrial enterprises (SIE) and Gross Domestic Product (GDP). The dependent variable for testing hypotheses 13 is the indicator of total innovation expenditure of industrial enterprises, and for hypothesis 4 is the indicator of GDP. The sample is created at the basis of data from statistical reports on the research and development activities of economic entities in Ukraine and on the Statistical Yearbook of Ukraine for the period 2000-2019 [6], [19-23].

Since there is a time lag between the innovation expenditures and the results of their implementation that has to be reflected by GDP growth, the total innovation expenditures of industrial enterprises with a lag of TIE ( $t$ -1) has be included into the model to test hypothesis H4.
To create the data sample for the regression analysis, information on the total innovation expenditure of industrial enterprises was obtained for the year 1999 till 2020, and for GDP numbers up to 2020 (preliminary estimates).

The regression analysis was chosen as main research method to test hypotheses about the relationship between 1) total innovation expenditure of industrial enterprises and their determinants and 2) total innovation expenditures of industrial enterprises and GDP. Data were analyzed using pooled regression with multiple explanation variables. Following model specifications support our analysis:

Model 1

$$
\begin{aligned}
T I E_{t} & =\alpha_{i}+\beta_{1 i} * \text { Size }_{t}+\beta_{2 t} * B L_{t}+ \\
& +\beta_{3 t} * F D I_{t}+\varepsilon_{i}
\end{aligned}
$$

Model 2

$$
G D P_{t}=\alpha_{i}+\beta_{1 i} * T I E_{t-1}+\beta_{2 t} * S I E_{t}+\varepsilon_{i}
$$

Where TIE represents: total innovation expenditure of industrial enterprises; Size show a volume of revenue from companies sales as the size of the companies; BL are the amount of bank loans granted to non-financial corporations; FDI is foreign direct investments.

\section{Results and Discussion}

Hypotheses testing is based on regression analysis. To answer the questions about the determinants defining the amount of the total innovation expenditure of industrial enterprises, a regression analysis was performed according to the identified Hypotheses 1-4. Descriptive statistics are given in Table 3.

The results of the calculations show that for the indicator of total innovation expenditure of industrial enterprises the average value for the entire period of the study is only 9035.5 million UAH, while the variability of this indicator by the coefficient of variation is $58 \%$, which is one of the least variable indicators of the group

\begin{tabular}{|c|c|c|c|c|}
\hline Variable & Min & Max & Mean & SD \\
\hline $\begin{array}{l}\text { Total innovation expenditure of industrial } \\
\text { enterprises }\end{array}$ & 1760,1 & 23229,5 & 9035,5 & 5257,9 \\
\hline Sales of industrial enterprises & 182700 & 3045202 & 1194533,1 & 916769,0 \\
\hline Bank Loan & 18594 & 859740 & 443706,3 & 316740,4 \\
\hline Foreign direct investment & 410,0 & 10913,0 & 4608,9 & 3020,5 \\
\hline $\begin{array}{l}\text { The share of innovatively active enterprises in } \\
\text { the total number of industrial enterprises }\end{array}$ & 8,2 & 16,6 & 12,8 & 2,2 \\
\hline GDP & 211200 & 3974564 & 1508060 & 1228486 \\
\hline
\end{tabular}
of indicators.

Table 3. Descriptive Statistics

The lowest variability is only share of innovatively active enterprises in the total number of industrial enterprises $-17 \%$ on the variation coefficient.

This confirms the conclusions of the preliminary descriptive analysis of the low and relatively constant level of expenditures on innovation among the industrial enterprises of Ukraine. The most variable indicator for the whole period is GDP with the variation coefficient of 0.81 , and in second place is the indicator Sales of industrial enterprises with the variation coefficient of $76 \%$. If we compare the amount of innovation costs and the amount of revenues of enterprises, we can see that 
they do not account for more than $0.8 \%$ of revenue. The share of innovative enterprises in the total value of all industrial enterprises is at most $16.6 \%$, which means that only every 6 th enterprise is engaged in innovation and its future development.

The next step is to present the results of a multiple regression analysis for the most common factors in the literature that influence the volume of innovation

Table 4. Results of multiple regression (Dependent $=$ Total innovation expenditure of industrial enterprises) expenditures of Ukrainian industrial enterprises (model 1). In describing the results of the regression analysis with three independent variables for total innovation expenditure (Table 4), it should be noted that bank loans (coefficient $=0.0764 *$ standard error $=0.0052)$ and foreign direct investment (coefficient $=0,0448 * *$, standard error $=0.2498$ ) were significant factors.

\begin{tabular}{|l|c|c|c|c|c|}
\hline \multicolumn{1}{|c|}{ Variables } & Coef & SD & t-stat & p-value & Result \\
\hline Constant & 515,7303 & 1790,606 & 0,28802 & 0,7771 & No hypothesis \\
\hline $\begin{array}{l}\text { Sales of industrial } \\
\text { enterprises }\end{array}$ & 0,0014 & 0,0018 & 0,7337 & 0,4737 & Not confirmed \\
\hline Bank Loans & 0,0099 & 0,0052 & 1,8948 & $0,0764^{*}$ & Confirmed \\
\hline $\begin{array}{l}\text { Foreign direct } \\
\text { investment }\end{array}$ & 0,5439 & 0,2498 & 2,1775 & $0,0448^{* *}$ & Confirmed \\
\hline Adj. R2 & \multicolumn{5}{|c}{0,6343} \\
\hline F-stat & \multicolumn{5}{|c|}{0,00023} \\
\hline F-stat (p-value) & \multicolumn{5}{|c|}{} \\
\hline
\end{tabular}

Note: *Significant at $10 \%,{ }^{* *}$ Significant at $5 \%,{ }^{* * *}$ Significant at $1 \%$

It is obtained that the regression coefficient for both variables is positive, although not significant. This means that the increase in the volume of bank loans and foreign direct investment has a positive effect on the volume of innovation expenditures of Ukrainian industrial enterprises and leads to economic growth. In addition, the adjusted coefficient of determination (Adj. R2) for the model at the level of $63 \%$ indicates sufficient explanatory power of the estimated model.

This confirms the previously obtained results of empirical analysis [15-16] for companies from other jurisdictions and confirms the conclusions of the report "Global Innovation Index - 2020" about the importance of the factor of access to finance. The descriptive analysis conducted to find the answer to the research question RQ4 also confirmed the importance of attracting funds in sufficient amounts, obtained from different sources and by different methods, to finance innovation. This result confirms the conclusions of Ukrainian scientists [3], [33], who note that the main factors constraining the implementation of innovation policy in enterprises are primarily financially based. The analysis showed (see table 2) that financing of the overwhelming majority of innovation costs by Ukrainian enterprises occurs at the expense of internal sources, which is due to both the risk of innovation activity and

Table 5. Results of multiple regression (Dependent $=$ GDP) the lack of opportunities to attract funds from investors and creditors. As noted in the study [3] low level of financing of innovative activities by domestic investors due to the lack of available funds, the high degree of uncertainty and risk inherent in innovative activities and the lack of legislative incentives for innovative activities.

Thus, we can conclude that hypotheses H2-H3 are confirmed for Ukrainian companies. But the hypothesis $H 1$ about the relationship between the amount of innovation costs and the size of the company was not confirmed for the Ukrainian context, which contradicts the previous research. The reasons may be both the insufficiency of the sample for the analysis and the fact that small technology companies in Ukraine are more active in implementing innovation.

Next, we tested the hypothesis of a positive impact of innovative development on the economic development of the country, which was evaluated by the GDP indicator. Two determinants that characterize the degree of innovativeness of the economy, namely the share of innovatively active enterprises in the total number of industrial enterprises and total innovation expenditure of industrial enterprises, were selected for evaluation (Table 5).

\begin{tabular}{|l|c|c|c|c|c|}
\hline \multicolumn{1}{|c|}{ Variables } & Coef & SD & t-stat & p-value & Result \\
\hline Constant innovation expenditure of & 134,0784 & 40,94259 & 3,27479 & $0,004467^{* *}$ & Confirmed \\
\hline $\begin{array}{l}\text { Total } \\
\text { industrial enterprises }\end{array}$ & 165662 & 1168431 & $-1,58817$ & 0,130673 & No hypothesis \\
\hline $\begin{array}{l}\text { The share of innovatively active } \\
\text { enterprises in the total number of } \\
\text { industrial enterprises }\end{array}$ & 168482,7 & 97395,56 & 1,729881 & 0,101764 & Not confirmed \\
\hline Adj. R2 & \multicolumn{5}{|l|}{$0,0,504$} \\
\hline F-stat & \multicolumn{5}{|l|}{0,000999} \\
\hline F-stat (p-value) &
\end{tabular}

Note: *Significant at $10 \%, * *$ Significant at $5 \%, * * *$ Significant at $1 \%$

According to the results of the test it was found that only one independent variable turned out to be significant, namely, the absolute amount of innovation expenditures of the previous period shows a positive connection with the level of gross domestic product $($ coefficient $=134.0784 * *$, standard error $=40.9426)$. 
Despite the lack of significance for other coefficients, the value of the adjusted coefficient of determination (Adj. R2) for the model at the 50\% level is significant. Results of testing of hypothesis $\mathrm{H} 4$ confirm that growth of investments into innovations, and in this case expenses on innovations, allows increasing opportunities to buy or develop for introduction of new technologies, to incur expenses on development of innovative products that in aggregate causes realization of more demanded new products or technologies. The increase in sales of innovative products also directly affects the size of the country's GDP.

Based on the calculations, we can derive a multiple regression model for innovation costs with weighting coefficients:

TIEt $=515,7303+0,0014 *$ Size $t+0,0099 * B L t+$

$$
0,5439 * F D I \mathrm{t},
$$

and a model for factors influencing economic development:

$$
G D P t=-1855662+134,0784 * \operatorname{TIE}(t-1)+168482,7 *
$$

$$
\text { SIE } t
$$

Least squares regression is based on several assumptions, in particular: linear dependence between variables, independence of regression residuals, normal distribution of variables and regression residuals, homoscedasticity and absence of multicollinearity. These assumptions were tested using appropriate tests for the two model specifications presented above. The White's test was used to check for heteroscedasticity, and the variance inflation factor was used to check for multicollinearity, for which there is a rule that its value should not exceed 10 . The value of the White's test and the variance factor were within the permissible limits for both cases. Thus, the permissibility of using the regression method for the analysis of the hypotheses was confirmed.

It should be noted that the conducted analysis has limitations due to the limited types and volumes of collected data, as statistical reports in Ukraine do not allow obtaining more detailed and diverse information about the innovative activity of enterprises to erect it into an equal panel of data (both for individual indicators and in the context of periods). This was repeatedly noted in previous studies for Ukrainian content [2]. Also Ukrainian companies do not have the obligation to publish different information on innovation activity indicators in the annual reports, does not allow forming a representative data panel. There is a discrepancy in the methodology and time frame for the data from the published reports of the NBU and the stock market, which also does not contribute to the formation of a comprehensive and balanced sample.

The choice of certain indicators as determinants of influence on innovation expenditure and GDP can be debatable for this research. Thus, innovativeness of economy can be estimated by indicators of introduction of innovations, volumes of realization of innovative products or their share in the total realization of products, according to some authors [2], [5] are more exact indicators. In addition, in some previous studies [9], the authors propose to use the GDP per capita indicator to assess the economic development of the country. There are also publications in which other methods of analysis are used to assess the influence of factors, in particular, in our opinion; the analysis carried out in this study by different methods (descriptive, comparative and regression methods) allows us to draw reasonable conclusions.

\section{Conclusions}

There is a two-side relationship between economic growth and innovation - the higher the amount of funds allocated to innovative activities, the higher is the effectiveness of such activities, and therefore, the higher is the volume of the country's GDP, and vice versa. It is believed that the more developed and richer the country, the more innovative it is and more is directed to innovation. The overwhelming majority of scientists, practitioners and politicians define availability of financial resources for scientific research and implementation of innovations as the key factor influencing the innovative activity of companies. It is the limited access to finance, the lack of free own funds does not allow companies and countries to develop innovations and condemns to poverty.

The analysis carried out in the work for the Ukrainian content provided answers to the research questions and confirmed that the state of innovation activity in the country is influenced by a complex of factors, including: macroeconomic factors, including monetary factors, the state and level of human capital development, access to funding from different sources. Since in Ukraine the greatest contribution to innovative activity is caused by the entrepreneurial sector, the research of the relationship between innovation and its determinants is carried out for industrial enterprises.

It was proved that the reduction in the number of employees engaged in innovation is directly related to the reduction of innovative activity of enterprises. It has been established that in Ukraine there is a steady decline in the number of workers involved in innovation, and in comparison with European countries, these indicators are much lower and tend to decrease further. This negatively affects the place of Ukraine in the global ranking of innovation. The relationship between the size of the company and the cost of innovation has not been tested.

It was found that there is a direct positive significant relationship between the volume of costs of innovation and the volume of bank loans and foreign direct investment in the equity of Ukrainian companies, confirms the thesis of access to finance as a driver of innovation. In addition, it was found that the reduction of interest rates on loans has a positive effect on the volume of lending to the economy and provides an increase in spending on innovation. Therefore, the practical value of this study is to substantiate the directions of development of the state strategy for innovation development, including the development of the financial market. To 
diversify the portfolio of financial resources available to finance innovative activities of companies, it is important to more widely introduce various methods and forms of financing (venture capital, microfinance, crowdfunding, financial technology) and attract funds from various participants, such as investment companies, non-profit organizations, various state and international funds of the relevant profile.

The direction for further research can be defined by studying the state of innovation activity in certain types of activities and depending on the size of the company.

\section{References}

1. M. Berdar, O. Yevtushevska, Baltic Journal of Economic Studies, 6 (2), 25-33 (2020) DOI: https://doi.org/10.30525/2256-0742/2020-6-2-25-31

2. L. Voloshchuk, Problems of the economy, 4, 269274 (2014)

3. 3. I. Gerasimova, Economic space, 137 55-67 (2018). DOI 10.30838/P.ES.2224.250918.55.227 http://prostir.pdaba.dp.ua/index.php/journal/article/v iew/301

4. I. Dovba, O. Djugovanetz Collection of scientific works of Uzhhorod National University, 1(24) 150161 (2020) DOI: $10.24144 / 2078$ 1431.2020.1(24).150-161

5. B. Seniv, Ja. Paranjuk, Economic space, 120 69-79 (2017)

6. 6. Scientific and innovative activities Ukraine 2019. Statistical publication (State Statistics Service of Ukraine, Kyiv, 2020)

7. V. Orlova, O. Kuzmenko, O. Sergeeva, European vector of economic development, 1(20) 112-120 (2016)

8. R. Maradana et al., Journal of Innovation and Entrepreneurship 6:1 (2017) DOI 10.1186/s13731016-0061-9

9. A. M.Pece et al., Procedia Economics and Finance 26461 - 467 (2015)

10. R.P. Pradhan, M. B. Arvin, J.H. Hall, M. Nair, Applied Economics Letters, 23(16), 1141-1144. (2016)

11. A. Barrichello, E. Gomes dos Santos, R. S. Morano, Innovation \& Management Review, 17(3) 307-320 (2020)DOI 10.1108/INMR-04-2019-0040

12. R. Stanisławski, Sustainability, 123290 (2020) doi:10.3390/su12083290

13. M. Bhattacharya, H. Bloch, Small Business Economics, 22 155-162 (2004). https://doi.org/10.1023/B:SBEJ.0000014453.94445. de

14. K. Širec, D. Močnik DOI: 10.5772/intechopen.71843 https://www.intechopen.com/books/entrepreneurshi p-development-tendencies-and-empiricalapproach/determinants-of-established-entrepreneursinnovative-activity-in-northern-and-western-europe
15. S. Girma, Yu. Gong, H. Gürg Article in The World Bank Economic Review (Kiel Institute for the World Economy, 2008)

16. K. Xu, Ch. Geng, X. Wei, H. Jiang, Journal of Business Economics and Management, 21 (4) 10101034 (2020) https://doi.org/10.3846/jbem.2020.12727

17. S. Dutta, B. Lanvin, S. Wunsch-Vincent (World Intellectual Property Organization, 2020) https://doi.org/978-2-9522210-8-5

18. Global Innovation Index http://www.globalinnovationindex.org/analysisindicator

19. Statistical Yearbook of Ukraine 2019. Statistical publication (State Statistics Service of Ukraine, Kyiv, 2020)

20. Statistical Yearbook of Ukraine 2011 Statistical publication (State Statistics Service of Ukraine, Kyiv, 2012)

21. Statistical Yearbook of Ukraine 2009 Statistical publication (State Statistics Service of Ukraine, Kyiv, 2010)

22. Monetary statistics NBU http://www.bank.gov.ua > files > 3.3-Loans.xls

23. GDP of Ukraine 2020 https://index.minfin.com.ua/ua/economy/gdp/

24. Ukrayina pokrashchila svoyu poziciyu v rejtingu globalnij innovacijnij indeks-2020, https://www.kmu.gov.ua/news/ukrayinapokrashchila-svoyu-poziciyu-v-rejtingu-globalnijinnovacijnij-indeks-2020

25. K. Kovtunenko et al., Innovative economics: theoretical and practical aspects: monograph (Kherson: Green DS, 2017)

26. J. R. Brown, G. Martinsson, B.C. Petersen, European Economic Review, 56 (8) 1512-1529 (2011) https://doi.org/10.2139/ssrn.1684731

27. A. Alam, M. Uddin, H. Yazdifar, R\&D Management, 49 (1), 21-32 (2019) https://doi.org/10.1111/radm.12303

28. X. F. Cao, Soft Science, 28 (12), 73-78 (2014) https://doi.org/10.3969/j.issn.1001$\underline{8409.2014 .12 .017}$

29. P. Chen, M. Yang, Communication of Finance and Accounting, 26 57-61 (2018)

https://doi.org/10.16144/j.cnki.issn10028072.2018.26.014

30. W. Hadhri, R. Arvanitis, H. M'Henni, Journal of Innovation Economics \& Management, 3 (21) 77 107 (2016)

31. L. Mamatova, Reporter of the Priazovskyi State Technical University, Economic sciences, 36279 291 (2018)

32. M. Cetin, International Journal of Economic and Administrative Studies, 6 (11), 1-16 (2013)

33. A. Kasych, K. Kanunikova, Investments: practice and experience, 22 21-24 (2016) 